\title{
Detection of infectious hematopoietic necrosis virus in cell culture fluid using immunoblot assay and biotinylated monoclonal antibody
}

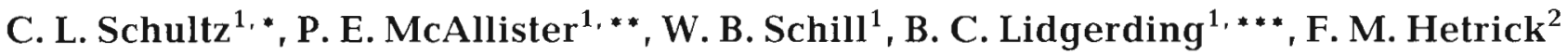 \\ ${ }^{1}$ U.S. Fish and Wildlife Service, National Fish Health Research Laboratory, Box 700, Kearneysville, West Virginia 25430, USA \\ ${ }^{2}$ Department of Microbiology, University of Maryland, College Park, Maryland 22807, USA
}

\begin{abstract}
Affinity purified monoclonal antibody was biotinylated and used with avidin-labeled peroxidase in an immunoblot assay to detect infectious hematopoietic necrosis virus (IHNV). The procedure proved capable of detecting the virus a titers as low as ca $10^{4}$ plaque forming units (PFUs) $\mathrm{ml}^{-1}$ of cell culture fluid, which corresponds to about $10^{2}$ PFUs spotted onto the immunoblot assay matrix. Time course studies showed that the detection of IHNV antigen in cell culture by immunoblot assay was directly related to the concentration of virus in the inoculum and that positive immunoblot reactions coincided with the appearance of cytopathic changes in inoculated cell cultures. We used the immunoblot assay to detect and identify IHNV antigen in medium from cells inoculated with ovarian fluids. Immunoblot assay was not suitable for detecting IHNV in raw ovarian fluid. When ovarian fluids from IHNV-negative chinook salmon Oncorhynchus tshawytscha and steelhead trout $O$. mykiss were assayed by the immunoblot method, false positive reactions results from the binding of monoclonal antibody to some of the ovarian fluid proteins. The advantages and limitations of the assay are discussed.
\end{abstract}

\section{INTRODUCTION}

Infectious hematopoietic necrosis (IHN) causes catastrophic losses in young salmonid fishes - primarily salmon and trout less than 6-mo old. The etiologic agent, infectious hematopoietic necrosis virus (IHNV), is transmitted through the water and putatively through contaminated reproductive fluids (Mulcahy et al. 1983, Mulcahy \& Pasco 1984, 1985). The virus is identified primarily by serum neutralization assay. Because IHNV is a poor immunogen, immunodiagnostic reagents are often limited in quality and quantity (Hill et al. 1980).

Schultz et al. (1985) developed a hybridoma cell line that secretes antibody specific for IHNV. In the present

- Present address: Department of Biologics Research, Division of Communicable Disease and Immunology, Walter Reed Army Institute of Research, Washington, D.C. 20307-5100, USA

- Addressee for reprint requests

-. Present address: Division of Virology, U.S. Army Medical Research Institute of Infectious Diseases, Fort Detrick. Frederick, Maryland 21701-5011, USA study, we purified and biotinylated the monoclonal antibody and used it in an immunoblot assay to detect and identify IHNV. We determined assay sensitivity and tested the assay using ovarian fluid samples from chinook salmon Oncorhynchus tshawytscha and steelhead trout $O$. mykiss.

\section{MATERIALS AND METHODS}

Cell cultures and viruses. Monolayer cultures of chinook salmon embryo (CHSE-214) and epithelioma papillosum cyprini (EPC) cells were propagated in Eagle's minimal essential medium (MEM) supplemented with $10 \%$ fetal bovine serum (MEM-10). The CHSE-214 cells were grown at $18^{\circ} \mathrm{C}$ and EPC cells at $23^{\circ} \mathrm{C}$. For virus propagation and infectivity assays, we maintained cells in MEM supplemented with $2 \%$ fetal bovine serum and $16 \mathrm{mM}$ Tris (MEM-2 Tris, $\mathrm{pH}$ 7.6) as described by Wolf \& Quimby (1973). All cell culture media contained 100 international units (I.U.) $\mathrm{ml}^{-1}$ penicillin and $100 \mathrm{ug} \mathrm{ml}^{-1}$ streptomycin. To screen cell cultures for microbial contamination, we used the bis- 
benzamide staining procedure described by Chen (1977) as modified by Schuitz et al. (1986). Slides of cultured cells were examined within $3 \mathrm{~h}$ of staining at a magnification of at least $500 \times$.

Stocks of IHNV (Oregon strain; Wingfield et al. 1969) and infectious pancreatic necrosis virus serotype VR299 (IPNV) were prepared in monolayer cultures of CHSE- 214 cells at $15^{\circ}$ and $18^{\circ} \mathrm{C}$. respectively.

Ovarian fluids. Ovarian fluid samples from chinook salmon and steelhead trout, provided by D. Mulcahy (U.S. Fish and Wildlife Service, Seattle National Fishery Research Center, Seattle, Washington 98115, USA), were shipped frozen and stored for several weeks at $-70^{\circ} \mathrm{C}$ until assayed. The chinook salmon ovarian fluids had been stored for $1.5 \mathrm{yr}$ at $-70^{\circ} \mathrm{C}$ and steelhead trout ovarian filuids for $\hat{0} \mathrm{w} \mathrm{k} d \mathrm{i}-70^{\circ} \mathrm{C}$ before they were shipped to us. D. Mulcahy also provided results of the initial infectivity assays of freshly collected ovarian fluids.

Infectivity assays. Plaque assays were performed as described by Wolf \& Quimby (1973) and viral infectivity was expressed as plaque forming units (PFU) $\mathrm{ml}^{-1}$.

When assayed for infectivity by end-point titration, cell culture medium and ovarian fluid were clarified by centrifugation at $850 \times \mathrm{g}$ for $30 \mathrm{~min}$ at $4{ }^{\circ} \mathrm{C}$. The supernatant fluid was diluted in MEM-2 Tris, and $50 \mu \mathrm{I}$ aliquots of the variously diluted fluids were assayed on drained monolayer cultures of EPC cells in 96-well microtiter plates. After samples had adsorbed for $90 \mathrm{~min}$ at $15^{\circ} \mathrm{C}$, the inoculum was aspirated and $200 \mu \mathrm{l}$ of MEM-2 Tris was added to each well. When samples were assayed in 8-well plates, drained monolayers were inoculated with 100 ul of sample and after adsorption the inoculum was aspirated and cells overlaid with $2 \mathrm{ml}$ of MEM-2 Tris. Incubation was continued for $7 \mathrm{~d}$ at $15^{\circ} \mathrm{C}$. The $50 \%$ end point of infectivity was calculated by the method of Reed \& Muench (1938), and virus titer was expressed as tissue culture infectious doses ( TCID $_{50}$ ) $\mathrm{mI}^{-1}$ Immunoblot assays were performed on cell culture fluids 48,72 , and $168 \mathrm{~h}$ after cell culture inoculation.

Virus purification. Monolayers of CHSE-214 cells were infected with IHNV at a multiplicity of infection of 0.01 PFU per CHSE-214 cell and incubated at $15^{\circ} \mathrm{C}$. Virus was concentrated and purified using the procedure of de Kinkelin (1972). Virus purity was evaluated by polyacrylamide gel electrophoresis (PAGE) and protein concentration determined by the method of Lowry et al. (1951) as described by Shatkin (1969).

Polyacrylamide gel electrophoresis. We fractionated purified virus and ovarian fluids by PAGE using a discontinuous $4 \%$ stacking and $10 \%$ resolving slab gel (Laemmli 1970) prepared as described in a manual by Hoefer Scientific Instruments (San Francisco, California 94107, USA). Constituent proteins were separated by electrophoresis at $25 \mathrm{~mA}$ for about $4 \mathrm{~h}$ (Towbin et al. 1979). Gels were stained with $0.125 \%$ Coomassie blue in $50 \%$ methanol for at least $2 \mathrm{~h}$ and destained in an aqueous solution containing $50 \%$ methanol and $10 \%$ acetic acid.

Western blot analysis. Viral and ovarian fluid proteins were separated by PAGE and transferred to the nitrocellulose membrane by electrophoresis for $45 \mathrm{~min}$ at $800 \mathrm{~mA}$ to prepare western blots (Burnette 1981). Protein bands on the nitrocellulose membrane were visualized by indirect immunoperoxidase staining using the antj-IHNV monoclonal antibody (unbiotinylated) and a commercial kit (Bio-Rad Laboratories, Richmond, California 94804, USA).

Biotinylation of monoclonal antibody. Monoclonal immunoglobulin $\mathrm{G}$ (IgG) was concentrated and purified using Protein A Sepharose CL-4B affinity chromatography, as described by Schultz et al. (1985). Because the procedures of Kendall et al. (1983) and Rao et al. (1983) used for biotinylation of polyclonal antibody resulted in over-biotinylation and complete loss of specificity, we carried out biotinylation as follows. Purified IgG was dialyzed against $0.1 \mathrm{M}$ sodium bicarbonate ( $\mathrm{pH} 8.2$ ) for $48 \mathrm{~h}$ at $4{ }^{\circ} \mathrm{C}$, and $1 \mathrm{mg}$ of $N$ hydroxysuccinimidobiotin $\left(34.1 \mathrm{mg} \mathrm{ml}^{-1}\right.$ in dimethyl sulfoxide) was added to $10 \mathrm{mg}$ of the IgG preparation. The mixture was gently stirred for $45 \mathrm{~min}$ at room temperature after which glycine (20 $\mu \mathrm{g}$ per $\mathrm{mg}$ of $\mathrm{IgG}$ ) was added to stop the reaction. The mixture was dialyzed for 4 d at $4^{\circ} \mathrm{C}$ against $0.05 \mathrm{M}$ sodium phosphate buffer ( $\mathrm{pH} 7.2)$, which was changed twice daily. The biotinylated IgG was stored at $4{ }^{\circ} \mathrm{C}$.

Immunoblot assays. To assay ovarian and cell culture fluids for viral antigen, we used modifications of the immunoblot procedures of Towbin \& Gordon (1984) and McAllister \& Schill (1986). Sample fluid (10 $\mu 1)$ was spotted onto Whatman 541 ashless filter paper (Whatman Chemical Separations, Inc., Clifton, New Jersey 07014, USA) and the paper then gently blown dry. Nonspecific adsorption sites were blocked by immersing the paper for $30 \mathrm{~min}$ in $4 \%$ bovine serum albumin prepared in calcium- and magnesium-free phosphate buffered saline (PBS: pH 7.2). The paper was then: (1) incubated for $1 \mathrm{~h}$ at $37^{\circ} \mathrm{C}$ in biotinylated anti-IHNV

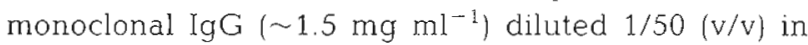
PBS; (2) washed 3 times in PBS containing $0.2 \%$ Tween-20; and (3) incubated at $37^{\circ} \mathrm{C}$ for $25 \mathrm{~min}$ in avidin-conjugated horseradish peroxidase (Bio-Rad Laboratories, Richmond, California 98404, USA) diluted $1 / 100(\mathrm{v} / \mathrm{v})$ in PBS containing $0.1 \%$ Tween-20. The Whatman 541 paper was washed 5 times with PBS containing $0.2 \%$ Tween-20 and then immersed in color developer for 5 to $10 \mathrm{~min}$. The color developer was prepared immediately before use by combining $2 \mathrm{ml}$ of $0.005 \%$ o-dianisidine dihydrochloride (prepared in. 
$70 \%$ dimethylformamide), $30 \mathrm{ml}$ of $\mathrm{PBS}$, and $30 \mu \mathrm{l}$ of $30 \%$ hydrogen peroxide. Positive reactions appeared as orange dots on the 541 paper (McAllister \& Schill 1986).

Following inoculation of cell cultures, the relationship between the immunoblot reaction and IHNV titer was determined by assaying aliquots $(5 \mu \mathrm{l})$ of cell culture fluid. Assays were conducted at 12 -h intervals from 24 to $96 \mathrm{~h}$ after cell culture inoculation.

Characterization of cross-reactive substances. To identify nonviral cross-reactive components present in ovarian fluids, we fractionated chinook salmon and steelhead trout ovarian fluids by PAGE. Reactive components were visualized by western blot analysis. For comparative purposes, purified IHNV proteins were included in the analysis.

\section{RESULTS}

\section{Biotinylated monoclonal antibody}

As mentioned earlier, biotinylation of the monoclonal antibody using the procedures of Kendall et al. (1983) and Rao et al. (1983) resulted in a complete loss of antibody specificity. Biotinylation using the procedure outlined by us yielded a more acceptable reagent. When used in the immunoblot assay, it detected IHNV antigen to $\sim 5.5 \mathrm{ng}$ and did not react with cell culture medium or IPNV antigen ( $\sim 550 \mathrm{ng})$ used as negative controls (data not shown). However, when we used the monoclonal antibody and the immunoblot assay to detect IHNV in raw ovarian fluid, we found that the monoclonal antibody reacted with components present in IHNV-free ovarian fluid (Fig. 1).

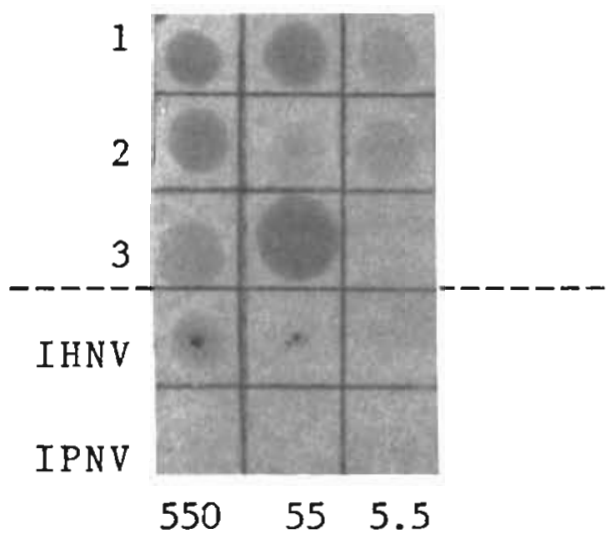

Fig. 1. Immunoblot reactivity of virus-free chinook salmon ovarian fluids, purified IHNV, and purified IPNV. Rows 1, 2 , and 3: immunoblot reactivity of 9 individual ovarian fluid samples; Row IHNV: immunoblot reactivity of (left to right) 550,55 , and $5.5 \mathrm{ng}$ of purified IHNV; row IPNV immunoblot reactivity (nil) of 550,55, and $5.5 \mathrm{ng}$ of purified IPNV

\section{Immunoblot detection of IHNV antigen in cell culture fluid}

The earliest time for immunoblot detection of IHNV antigen in cell culture fluid was $36 \mathrm{~h}$, a result that was directly related to the concentration of the virus in the inoculum (Table 1). Viral antigen was detected at $36 \mathrm{~h}$

Table 1. Detection of IHNV antigen in cell culture fluids using biotinylated monoclonal antibody in an immunoblot assay. Immunoblot reactivity observed $(+)$ or not observed $(-)$ in fluids from CHSE-214 cells inoculated with IHNV Approximate PFU's of virus inoculated onto CHSE-214 cells in 8-well plates based on dilution of stock virus suspension. Fluid from an uninfected culture of CHSE-214 cells was used as negative control

\begin{tabular}{|lllllllll|}
\hline $\begin{array}{l}\text { Virus inoculated } \\
\text { (PFU) }\end{array}$ & \multicolumn{8}{cc|}{ Hours post infection } \\
& 24 & 36 & 48 & 60 & 72 & 84 & 96 \\
$\sim 4.2 \times 10^{3}$ & - & + & + & + & + & + & + \\
$\sim 4.2 \times 10^{2}$ & - & - & + & + & + & + & + \\
$\sim 4.2 \times 10^{1}$ & - & - & - & + & + & + & + \\
$\sim 4.2 \times 10^{0}$ & - & - & - & - & + & + & + \\
$\sim 4.2 \times 10^{-1}$ & - & - & - & - & - & - & - \\
Control & - & - & - & - & - & - & - \\
\hline
\end{tabular}

when the highest level of input virus was used $\left(\sim 4.2 \times 10^{3}\right.$ PFU). However, viral antigen was not detected until $72 \mathrm{~h}$ with a virus input of $\sim 4.2 \times 10^{\circ} \mathrm{PFU}$, and it was never detected in cells exposed to $-4.2 \times 10^{-1}$ PFU. Positive immunoblot reactions coincided with the appearance of CPE in the cell cultures. The virus titer in CHSE-214 cell cultures at $72 \mathrm{~h}$ after inoculation was $10^{5} \mathrm{PFU} \mathrm{ml} \mathrm{m}^{-1}$ or greater. No CPE occurred at the lowest level of input virus $\left(-4.2 \times 10^{-1} \mathrm{PFU}\right)$.

\section{Characterization of nonviral immunoblot reactivity in ovarian fluid of chinook salmon}

Initial immunoblot assays showed that supernatants of virus-free ovarian fluid from chinook salmon was immunoblot-positive whereas that from steelhead trout was not. However, western blots showed that ovarian fluid from both species contained immuno-reactive components. Variations in the intensity of immunoblot color suggested that chinook salmon ovarian fluids contained differing amounts of the cross-reactive component(s) (Fig. 1).

A comparison of polyacrylamide gels (Fig. 2) and western blots (Fig. 3) of purified IHNV protein and of steelhead trout ovarian fluids showed that certain of the ovarian fluid proteins reacted with monoclonal IgG. The migration rates of cross-reactive proteins differed from those of IHNV proteins but were most similar to 

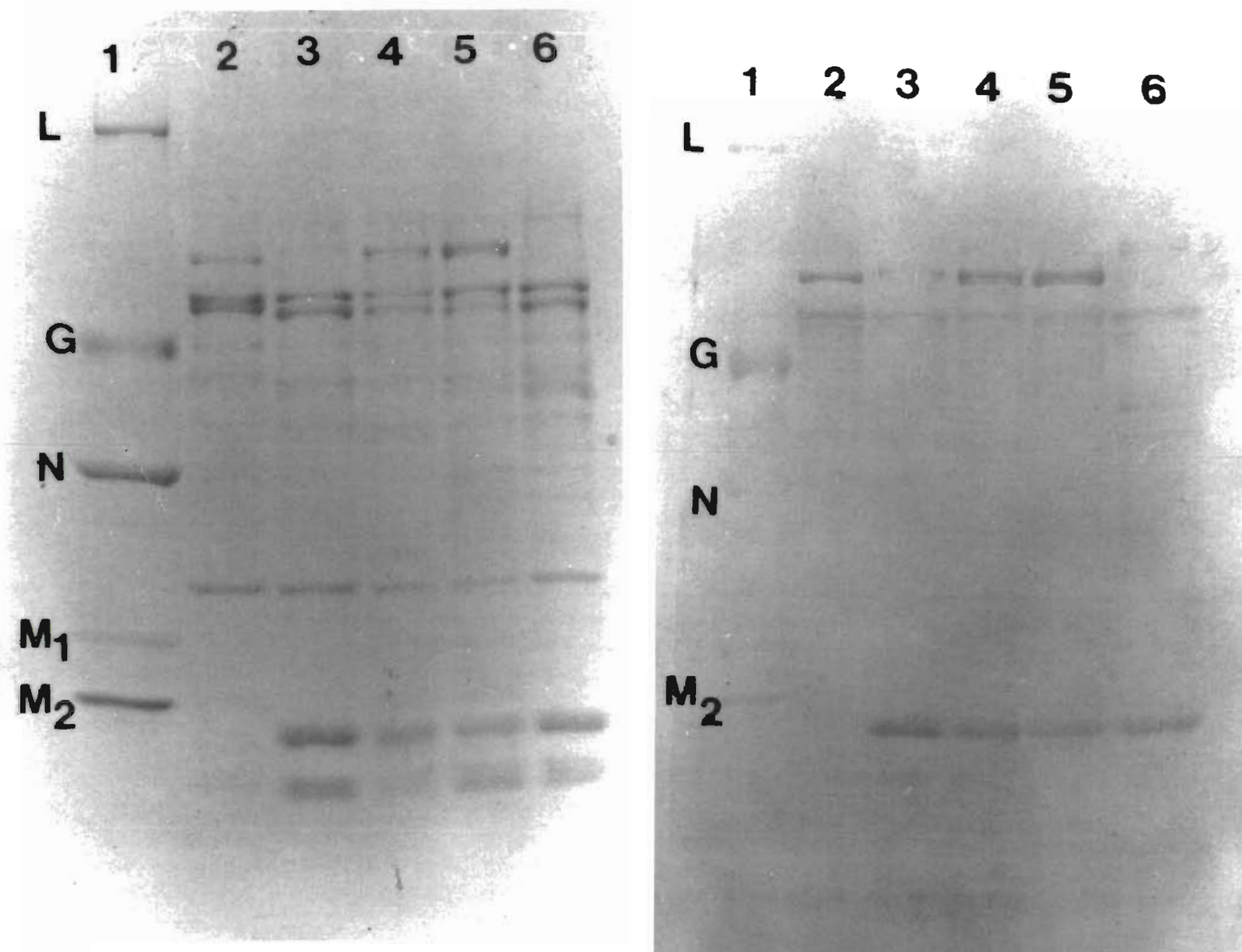

Fig. 2. Polyacrylamide gel of purified IHNV proteins $\{L, G, N$ $M_{1}, M_{2}$ ) and of steelhead trout ovarian fluids, Lane 1: purified IHNV; Lane 2: steelhead trout ovarian fluid seeded with IHNV, Lanes 3 to 6 : virus-free steelhead trout ovarian fluids

those of IHNV G and $M_{2}$ proteins (MCAllister \& Wagner 1975. McAllister 1979). Similar results were seen with chinook salmon ovarian fluids (data not shown).

\section{Detection of IHNV in ovarian fluids of chinook salmon and steelhead trout}

Ovarian fluids of chinook salmon and steelhead trout were assayed for IHNV using EPC cells, and medium from inoculated cultures was assayed for IHNV antigen by the immunoblot method. Some 42 ovarian fluid samples from chinook salmon were assayed and representative results are shown in Table 2 . In concurrent immunoblot and infectivity assays, both IHNV antigen and infectivity were detected in the culture fluids from 18 samples $(43 \%) ; 19$ samples $(45 \%)$ were both IHNV antigen and infectivity negative; and 5 samples (12\%)

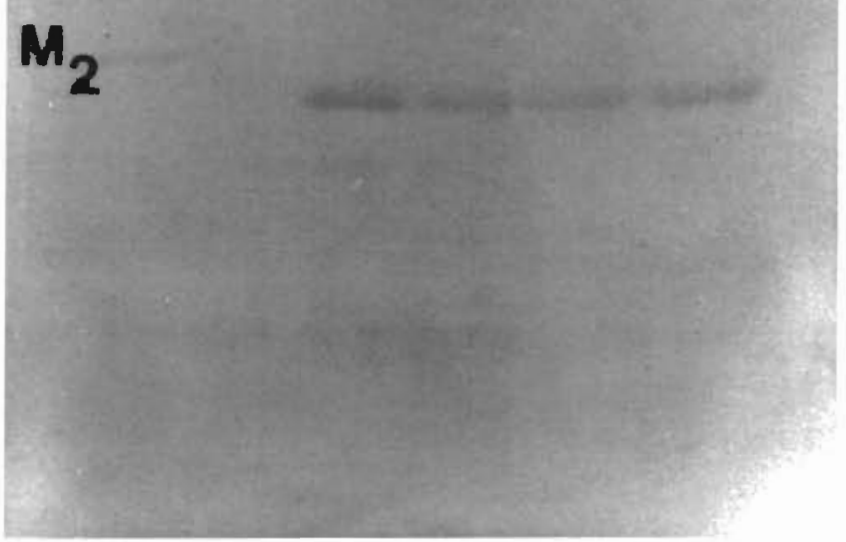

Fig. 3. Western blot of purified IHNV proteins (L, G, N, M and of steelhead trout ovarian fluids. Viral and ovarian fluid proteins, fractionated by PAGE and shown in Fig, 2, were transferred to a nitrocellulose membrane and reacted with anti-IHNV monoclonal IgG. Lane 1 purified IHNV; Lane 2: steelhead trout ovarian fluid seeded with IHNV: Lanes 3 to 6 : virus-free steelhead trout ovarian fluids

showed immunoblot reactivity but no measurable IHNV infectivity. The time required to detect IHNV antigen in cell culture fluid depended on the initial virus concentration - the greater the sample virus titer the earlier the viral antigen was detected. Most cell culture fluids were immunoblot positive 2 to $3 \mathrm{~d}$ after inoculation, but for some, immunoblot-positive reactions were not evident until $7 \mathrm{~d}$ after inoculation. Positive immunoblot reactions occurred in culture fluids ranging in virus titer from ca $10^{4}$ to $10^{3} \mathrm{TCID}_{50} \mathrm{ml}^{-1}$ (or $10^{2}$ to $10^{7}$ TCID $_{50}$ when spotted on the immunoblot matrix). 
Table 2. Representative results of immunoblot assays using biotinylated monoclonal antibody to detect IHNV antigen in fluids from EPC cultures inoculated with chinook salmon ovarian fluids. Original virus titer assays performed at the Seattle National Fishery Research Center in 1983, no infectivity detected (-); titer of EPC inoculum: assays performed at the National Fish Health Research Laboratory in 1985, no infectivity detected (-); immunoblot reactivity: detected (+), or not detected (-) at time indicated after cell culture inoculation

\begin{tabular}{|lcccc|}
\hline $\begin{array}{l}\text { Sample } \\
\text { no. }\end{array}$ & $\begin{array}{c}\text { Original virus titer } \\
(\text { PFU ml }\end{array}$ & $\begin{array}{c}\text { Titer of EPC inoculum } \\
\left.\text { (TCID } \mathrm{ml}^{-1}\right)\end{array}$ & $\begin{array}{c}\text { Immunoblot } \\
\text { results }\end{array}$ & $\begin{array}{c}\text { Virus titer of fluids used } \\
\text { in immunoblot test } \\
\left(\mathrm{TCID}_{50} \mathrm{ml}^{-1}\right)\end{array}$ \\
\hline 4 & $1.6 \times 10^{8}$ & $6.4 \times 10^{6}$ &,$+ 48 \mathrm{~h}$ & $4.7 \times 10^{8}$ \\
5 & $6.9 \times 10^{6}$ & $6.4 \times 10^{3}$ &,$+ 48 \mathrm{~h}$ & $6.4 \times 10^{7}$ \\
6 & $1.7 \times 10^{2}$ & $9.4 \times 10^{2}$ &,$+ 48 \mathrm{~h}$ & $9.4 \times 10^{3}$ \\
11 & $1.7 \times 10^{8}$ & $6.4 \times 10^{4}$ &,$+ 72 \mathrm{~h}$ & $6.4 \times 10^{5}$ \\
12 & $5.3 \times 10^{3}$ & $<10^{1}$ &,$+ 72 \mathrm{~h}$ & $6.4 \times 10^{4}$ \\
13 & $5.4 \times 10^{2}$ & $9.4 \times 10^{2}$ &,$+ 7 \mathrm{~d}$ & $1.0 \times 10^{9}$ \\
14 & $9.5 \times 10^{1}$ & $<10^{1}$ &,$- 7 \mathrm{~d}$ & $-2 \times 10^{8}$ \\
19 & $2.6 \times 10^{6}$ & $<10^{1}$ & - & - \\
Cell control & - & - & - & - \\
Medium control & - & - & & - \\
\hline
\end{tabular}

Table 3. Representative results of immunoblot assays using biotinylated monoclonal antibody to detect IHNV antigen in fluids from EPC cultures inoculated with steelhead trout ovarian fluids. Original virus titer: assays performed at the Seattle National Fishery Reserach Center in 1985, no infectivity detected (-); titer of EPC inoculum: assays performed at the National Fish Health Research Laboratory in 1985, no infectivity detected (-); immunoblot reactivity: detected $(+)$, or not detected $(-)$ at time indicated after cell culture inoculation

\begin{tabular}{|c|c|c|c|c|}
\hline $\begin{array}{l}\text { Sample } \\
\text { no. }\end{array}$ & $\begin{array}{l}\text { Original virus titer } \\
\qquad\left(\mathrm{PFU} \mathrm{ml} \mathrm{m}^{-1}\right)\end{array}$ & $\begin{array}{l}\text { Titer of EPC inoculum } \\
\qquad\left(\mathrm{TCID}_{50} \mathrm{ml}^{-\mathrm{i}}\right)\end{array}$ & $\begin{array}{l}\text { Immunoblot } \\
\text { results }\end{array}$ & $\begin{array}{l}\text { Virus titer of fluids used } \\
\text { in immunoblot test } \\
\left.\text { (TCID } \mathrm{ml}_{50}^{-1}\right)\end{array}$ \\
\hline 43 & $5.0 \times 10^{3}$ & $9.4 \times 10^{2}$ &,$+ 48 \mathrm{~h}$ & $3.4 \times 10^{7}$ \\
\hline 44 & $3.2 \times 10^{5}$ & $2.0 \times 10^{5}$ &,$+ 48 \mathrm{~h}$ & $4.2 \times 10^{8}$ \\
\hline 46 & $2.8 \times 10^{3}$ & $2.0 \times 10^{2}$ & $+.48 \mathrm{~h}$ & $9.4 \times 10^{3}$ \\
\hline 60 & $1.3 \times 10^{3}$ & $3.4 \times 10^{2}$ & $+.72 h$ & $9.4 \times 10^{3}$ \\
\hline 65 & $2.8 \times 10^{4}$ & $2.0 \times 10^{3}$ & $+.72 \mathrm{~h}$ & $9.4 \times 10^{5}$ \\
\hline 66 & $4.0 \times 10^{5}$ & $6.4 \times 10^{4}$ & $+.72 \mathrm{~h}$ & $2.0 \times 10^{8}$ \\
\hline 70 & $2.8 \times 10^{5}$ & $<10^{\prime}$ & $-.7 \mathrm{~d}$ & - \\
\hline 71 & $1.2 \times 10^{2}$ & $<10^{1}$ & $-7 d$ & - \\
\hline Cell control & - & - & - & - \\
\hline Medium control & - & - & - & - \\
\hline
\end{tabular}

Forty ovarian fluid samples from steelhead trout were assayed; representative results are shown in Table 3. Both IHNV antigen and infectivity were detected in 27 cell culture fluid samples (68\%) while 13 samples (32\%) were both IHNV antigen and infectivity negative. Positive immunoblot reactions were evident 2 to 3 d after cell culture inoculation. The virus titer of immunoblot-positive cell culture fluids ranged from ca $10^{4}$ to $10^{8} \mathrm{TCID}_{50} \mathrm{mll}^{-1}\left(10^{2}\right.$ to $10^{6} \mathrm{TCID}_{50}$ when spotted on the immunoblot matrix). A representative culture fluid immunoblot assay is shown in Fig. 4.

The cell culture incubation time required to detect antigens by immunoblot assay was greater for chinook salmon ovarian fluids that had been stored at $-70^{\circ} \mathrm{C}$ for $1.5 \mathrm{yr}$ than for those from steelhead trout stored for $6 \mathrm{wk}$. Our previous results showed that incubation time was directly affected by the concentration of infectious virus in the inoculum. Although the infectivity assays are not directly comparable, the initial virus plaque titers provided by Mulcahy were in general much higher than the end-point virus titers determined when we thawed the ovarian fluid samples. Apparently, storage at $-70^{\circ} \mathrm{C}$ caused a considerable decrease in the infectious virus titer of the ovarian fluids.

\section{DISCUSSION}

We have developed an assay for detection of IHNV antigen in cell culture fluid using biotinylated monoclonal antibody. The procedures we initially used to biotinylate monoclonal IgG preparations caused overbiotinylation and loss of specificity. Ultimately, manipulation of reagent concentrations and reaction time 


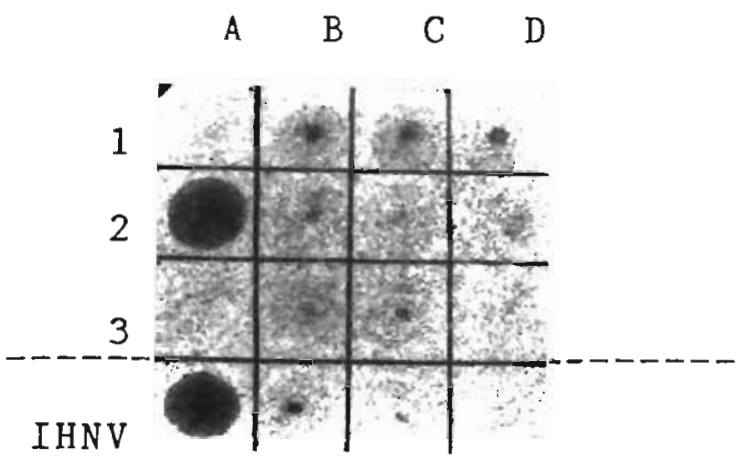

\section{$\begin{array}{llll}550 & 55 & 5.5 & \mathrm{CCM}\end{array}$}

Fig. 4. Immunoblot assay of fluids from cell cultures inoculated with chinook salmon ovarian fluids. Rows 1 to 3 : immunoblot reactivity of fluids from inoculated cell cultures. Sites $1 \mathrm{~A}, 3 \mathrm{~A}$, and $3 \mathrm{D}$ show no reactive IHNV antigen; Row IHNV. immunoblot reactivity of (left to right) 550,55 , and $5.5 \mathrm{ng}$ of purified IHNV and no immunoblot reactivity with cell culture medium (CCM)

resulted in reliable biotinylation. Using biotinylated IgG in the immunoblot assay, we detected purified IHNV antigen in amounts as low as $5.5 \mathrm{ng}$ and detected viral antigen in cell culture fluids 36 to $72 \mathrm{~h}$ after inoculation

Initial trials with virus-free and virus-seeded ovarian fluids showed that variable levels of endogenous immunoblot reactivity masked the reliable detection of viral antigen. Although we first believed that the reactivity might be due to peroxidase, tests for endogenous peroxidase activity revealed none (data not shown). Western blot analysis showed that the IgG reacted with several IHNV structural proteins $\left(L, G\right.$, and $M_{2}$ and possibly $\mathrm{N}$ ). In addition, it also reacted with certain proteins present in ovarian fluid. This cross-reactivity could be explained if the proteins shared a common epitope.

We used cell culture inoculation to amplify IHNV antigen so that cross-reactivity with ovarian fluid proteins would be minimized. Tests indicated that IHNV antigen could be detected in cell culture fluids through a wide range of titers $\left(10^{4}\right.$ to $\left.10^{8} \mathrm{TCID}_{50} \mathrm{ml}^{-1}\right)$. Actually, the test detects $10^{2}$ to $10^{6} \mathrm{TCID}_{50}$ because only $10 \mu \mathrm{l}$ of fluid is spotted onto the immunoblot matrix. Sensitivity at titers as low as $10^{4} \mathrm{TCID}_{50} \mathrm{ml}^{-1}$ might permit further dilution of culture fluids to further reduce the chances of false-positive results due to cross-reacting ovarian fluid proteins. We are unsure of the significance of the false-positive immunoblot reactions observed with a few of the culture fluids from cells inoculated with chinook salmon ovarian fluid. The chinook ovarian fluids had been stored for a prolonged period (1.5 yr) before we received them for assay Conceivably, degenerative changes in addition to loss of infectivity could have occurred during the extended storage, rendering the chinook ovarian fluids unsuitable for immunoblot assay. We saw no such false-positive reactions with culture fluids from cells inoculated with steelhead ovarian fluid that had been stored for several weeks.

Viral antigen was generally detected $72 \mathrm{~h}$ after culture inoculation, and positive immunoblot reactions occurred when distinct CPE was evident. Some ovarian fluid samples required longer cell culture incubation, probably because they contained lower virus titers than others and perhaps because of the presence of virusinhibiting substances in the fluid, possibly resulting from storage at $-70^{\circ} \mathrm{C}$. Burke and Mulcahy (1983) reported the gradual loss of viral infectivity in rainbow trout ovarian fluid seeded with IHNV and stored at $-20^{\circ} \mathrm{C}$. Frozen storage of uvarian fluid samples therefore appears to be contraindicated.

Even though cell cultures must be inoculated with ovarian fluids and incubated to amplify viral antigen, the total time required to detect and identify IHNV in clinical samples and the amount of reagent required is considerably reduced as compared to that needed for serum neutralization assays. Usually sufficient antigen is produced after $72 \mathrm{~h}$ in culture to demonstrate immunoblot reactivity, and the immunoblot assay can be completed in $4 \mathrm{~h}$.

We are investigating the use of monoclonal antibody for detection of IHNV antigen by immunofluorescent assay, which would most probably further reduce the time required to detect and identify IHNV in infected cell cultures.

Acknowledgements. We thank P. E. Eschmeyer, R. L. Herman, P. W. Reno, and R. C. Simon for reviewing the manuscript $_{i}$ D. A. Ballenger, B. D. Lawson, and R. B. Owens for secretarial and editorial assistance; G. S. Gutsell for preparing the graphics; and H. M. Stuckey for the photography. The research was sponsored by the U.S. Department of Energy Grant DE-A179-84BP11890 from the Bonneville Power Administration.

\section{LITERATURE CITED}

Burke, J., Mulcahy, D. (1983). Retention of infectious haematopoietic necrosis virus infectivity in fish tissue homogenates and fluids stored at three temperatures. J. Fish Dis. 6: 543-547

Burnette, W. N. (1981). Western blotting: electrophoretic transfer proteins from sodium dodecyl sultate-polyacrylamide gels to unmodified nitrocellulose and iodiographic detection with antibody and radioiodinated protein $A$. Analyt. Biochem. 112: 195-201.

Chen, T. R. (1977). In situ detection of mycoplasma contamination in cell cultures by fluorescent Hoechst 332.58 stain. Expl. Cell Res. 104: 255-258

de Kinkelin, P. (1972), Le virus d'Egtved. II Purification. Ann. Rech. Vet. 3: 199-209

Hill, A. J., Williams, R. F., Finlay, J. (1980). Preparation of antisera against fish disease. Dev. Biol. Stand. 49: 209-221 
Kendall, C., Ionescu-Matiu, I., Dreesman, G. R. (1983). Utilization of the biotin/avidin system to amplify the sensitivity of the enzyme-linked immunosorbent assay (ELISA). J. Immun. Meth. 56: 329-339

Laemmli, U. E. (1970). Cleavage of structural proteins during the assembly of the head of bacteriophage T4. Nature, Lond. $227 \cdot 680-689$

Lowry, O. H., Rosebrough, N. J., Farr, A. L., Randall, R. J. (1951). Protein measurement with the Folin phenol reagent. J. biol. Chem. 193: 265-274

McAllister, P. E. (1979). Fish viruses and viral infections. In: Fraenkel-Conrat, H., Wagner, R. R. (eds.) Comprehensive virology, vol. 14. Plenum Publishing Corp., New York, p. $401-470$

McAllister, P. E. Schill, W. B. (1986). Immunoblot assay: a rapid and sensitive method for identification of salmonid fish viruses. J. Wildl. Dis. 22(4): 468-474

McAllister, P. E., Wagner, R. R. (1975). Structural proteins of two salmonid thabdoviruses. J. Virology 15: 733-738

Mulcahy, D., Pascho, R. J. (1984). Adsorption to fish sperm of vertically transmitted fish viruses. Science 225: 333-335

Mulcahy, D., Pascho, R. J. (1985). Vertical transmission of infectious haematopoietic necrosis virus in sockeye salmon, Oncorhynchus nerka (Walbaum): isolation of virus from dead eggs and fry. J. Fish Dis. 8: 393-396

Mulcahy, D., Pascho, R. J., Jenes, C. K. (1983). Detection of infectious haematopoietic necrosis virus in river water and demonstration of waterborne transmission. J. Fish Dis. 6: 321-330

Rao, P. V S., McCarty-Francis, N. L., Metcalfe, D. D. (1983).

Responsible Subject Editor: Dr T Evelyn, Nanaimo, B.C., Canada
An avidin-biotin micro ELISA for rapid measurement of fatal and alergen-specific human $\lg$ E. J. Immun. Meth. 57 : $71-82$

Reed, L. J., Muench, H. (1938). A simple method of estimating fifty percent endpoints. Am. J. Hyg. 27. 493-502

Schultz, C. L., Lidgerding, B. C., McAllister, P. E., Hetrick, F. M. (1985). Production and characterization of monoclonal antibody against infectious haematopoietic necrosis virus. Fish Pathol. 20: 339-341

Schultz, C. L., Lidgerding, B. C., McAllister, P. E., Hetrick, F. M. (1986). Mycoplasma contamination in fish cell lines: an evaluation of detection by differential incorporation of ${ }^{3} \mathrm{H}$ uridine and ${ }^{14} \mathrm{C}$-uracil. J. Fish Dis. 9: 117-122

Shatkin, A. J. (1969). Colorimetric reactions for DNA, RNA, and protein determinations. In: Habel, K., Salzman, N. P. (eds.) Fundamental techniques in virology. Academic Press, New York, p. 231-237

Towbin, H., Gordon, J. (1984). Immunoblotting and dot inınunobinding - current status and outlook. J. Immun. Meth. 72: 313-324

Towbin, H., Staehelin, T., Gordon, J. (1979). Electrophoretic transfer of proteins from polyacrylamide gels to nitrocellulose sheets: procedure and some applications. Proc. natn. Acad. Sci. U.S.A. 76: 4350-4354

Wingfield, W. H., Fryer, J. L., Pilcher, K. S. (1969). Properties of the sockeye salmon virus (Oregon strain). Proc. Soc exp. Biol. Med. 130: 1055-1059

Wolf, K., Quimby, M. C. (1973). Fish viruses: buffers and methods for plaquing eight agents under normal atmosphere. Appl. Microbiol. 25: 659-664

Manuscript first received: March 11, 1987

Revised version accepted: June 19, 1989 